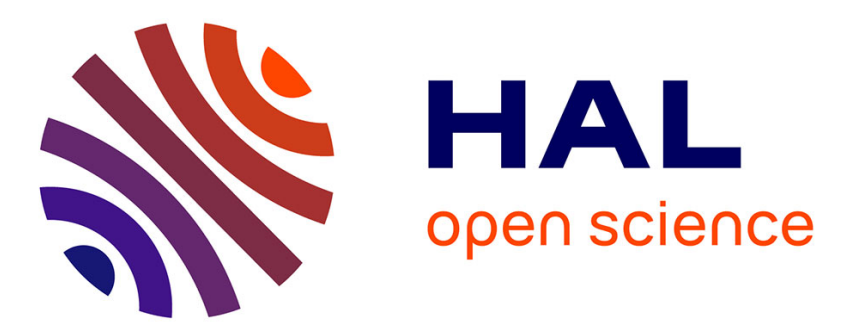

\title{
Risk of wind-driven resuspension and transport of contaminated sediments in a narrow marine channel confluencing a wide lagoon
}

\author{
Elena Alekseenko, Bernard Roux
}

\section{- To cite this version:}

Elena Alekseenko, Bernard Roux. Risk of wind-driven resuspension and transport of contaminated sediments in a narrow marine channel confluencing a wide lagoon. Estuarine, Coastal and Shelf Science, 2020, 237, pp.106649. 10.1016/j.ecss.2020.106649 . hal-03251615

\author{
HAL Id: hal-03251615 \\ https://hal.science/hal-03251615
}

Submitted on 7 Jun 2021

HAL is a multi-disciplinary open access archive for the deposit and dissemination of scientific research documents, whether they are published or not. The documents may come from teaching and research institutions in France or abroad, or from public or private research centers.
L'archive ouverte pluridisciplinaire HAL, est destinée au dépôt et à la diffusion de documents scientifiques de niveau recherche, publiés ou non, émanant des établissements d'enseignement et de recherche français ou étrangers, des laboratoires publics ou privés. 


\title{
Risk of wind-driven resuspension and transport of contaminated sediments in a narrow marine channel confluencing a wide lagoon
}

\author{
E. Alekseenko ${ }^{a, b, *}$, B. Roux ${ }^{c}$ \\ ${ }^{a}$ Shirshov Institute of Oceanology, Russian Academy of Sciences, Nakhimovsky Prospekt 36, 117997, Moscow, Russia \\ ${ }^{\mathrm{b}}$ Laboratoire des Sciences du Climat et de l'Environnement (LSCE/IPSL), CEA Saclay, Gif-sur-Yvette, 91191, France \\ ${ }^{\mathrm{c}}$ Aix-Marseille Université, CNRS, Centrale Marseille, M2P2 UMR 7340, 13451, Marseille, France
}

\section{A R T I C L E I N F O}

\section{Keywords:}

Hydrodynamics in marine channel

Numerical modelling

Bottom shear stress due to wind

Resuspension of contaminated muddy sediments

\begin{abstract}
A B S T R A C T
This work concerns the wind-driven resuspension in a narrow marine channel and the risk of transport of contaminated bottom sediments in a wide brackish lagoon in the context of a planned anthropogenic infrastructure (with forced convection, by pumping sea water). It is based on the modelling and 3D numerical simulation of salinity, current distributions and bottom shear stress (BSS). The goal is to demonstrate that, even for narrow channels of a few tens of meter of width, a wind of $10-20 \mathrm{~m} / \mathrm{s}$ is sufficient to create intensive currents, to resuspend muddy bottom sediments and transport polluted sediments downstream. Several model scenarios are considered for such wind speeds in two dominant and opposite wind directions, for a channel whose bottom sediments are mainly constituted of fine particles, typically $85 \%$ of mud and $15 \%$ of fine sand. It is known that finer sediments usually play an important role to transport contaminants (due to larger surface area of smaller particles). Our main results concern the bottom shear stress along such a long and narrow channel; namely the Rove channel which confluences the Etang de Berre lagoon, and for which a project of forced current circulation is planned by pumping sea water. Our numerical results show that the mobility threshold can be easily overpassed for the muddy sediments in the Rove channel. For a bottom roughness of $5 \mu \mathrm{m}$ (coarse silt) and a wind speed of $20 \mathrm{~m} / \mathrm{s}$, BSS can reach $0.18 \mathrm{~N} / \mathrm{m}^{2}$ for the N-NW wind in the median part of the channel, and even 0.21 $\mathrm{N} / \mathrm{m}^{2}$ in one enlargement for the S-SE wind, while $\mathrm{BSS}_{\mathrm{cr}}$ is about $0.1 \mathrm{~N} / \mathrm{m}^{2}$. We conclude that these local winds can permit floc erosion and even surface erosion of fine sediments in the Rove channel.

Concerning the resuspension of muddy sediments, our results are consistent with the experimental study presented by Carlin et al. (2016) for a windy shallow lagoon. They are also consistent with the conclusion of Mengual et al. (2017), from erodimetry experiment for estuarine sediments, that the sediment behaves like a pure mud if the percentage of the mud fraction is more than $70 \%$, and that the critical BSS for mobility of such bed sediments is of the order of $0.1 \mathrm{~N} / \mathrm{m}^{2}$. Such a lower critical BSS when the mixture is muddier is opposite to trends most often published.
\end{abstract}

\section{Introduction}

The present work concerns a 3D numerical simulation of hydrodynamics and sedimentary transport of pollutants in a long and narrow channel (called Rove) in a windy area. It is realized in the context of an old and complex anthropogenic project of partial reopening of a collapsed tunnel (Ramade, 1997). This reopening is planned to remediate the bottom sediment of this channel and, possibly, to control the salinity level of an adjacent hydrosystem: the Bolmon lagoon. The project itself consists to pump sea water, with a given flow rate (runoff), from the Bay of Marseille, to create a flow in this long channel that confluences with Etang de Berre (EB) which is a wide brackish lagoon. But, the selection of the level of such a sea water runoff (in the range of $4-20 \mathrm{~m}^{3} / \mathrm{s}$ ) is still controversial for different reasons (see Abrial and Hucher, 2017).

Until its collapse in 1963, the Rove tunnel (about $7 \mathrm{kms}$ ) was used for freight transport by ship from Marseille's harbor to the Rhone River (via the Gulf of Fos). After this collapse, the entrance of marine water was fully stopped, creating a source of pollution due to an almost permanent water stagnation in the Rove channel $(7.2 \mathrm{kms})$. This stagnation creates a negative environmental impact for nautical activities (rowing, waterskiing, canoeing-kayaking) which are today developed in the Rove

\footnotetext{
* Corresponding author. Shirshov Institute of Oceanology, Russian Academy of Sciences, Nakhimovsky Prospekt 36, 117997, Moscow, Russia.

E-mail address: lena.alekseenko@gmail.com (E. Alekseenko).
} 
channel.

In the perspective of such a reopening (with different pumped mass flow rates), a detailed analysis of the sediments characteristics has been carefully performed by IDRA (2011). This analysis shows that the bed sediments are muddy and points out different alarming ecological and environmental problems: (a) about the bad quality of the marine water to be pumped from Marseille Bay, (b) due to a severe concentration of contaminants in the sediments of Rove channel, (c) an evident risk to contaminate two downstream lagunar hydrosystems (i.e., Etang de Berre and Bolmon lagoons).

The present study was decided in the context of this anthropogenic project. It represents a first step where the goal is to determine the Bottom Shear Stress (BSS) in the Rove channel, and to compare it to its critical value for the erosion and resuspension of bed sediments in terms of their granular properties, characterized by their bottom roughness.

It is important to consider the resuspension of bed sediments by wind forcing. Carlin et al. (2016), by realizing in situ experiments of suspended sediment concentration (SSC) into a shallow lagoon, showed the importance of meteorological frontal passage of frequent occurrence. Their results show an interesting relationship between wind stress and sediment resuspension; peaks in near-bed SSC corresponding to peaks in wind speed.

Another goal of the present study concerns the influence of a forced convection in the Rove channel on salinity changes which could also influence adjacent lagunar hydrosystems, in particular the salinity level of the Bolmon lagoon that need to stay in a certain range (Alekseenko and Roux, 2019a).

The risk of the downstream transport of contaminated sediments depends on the SSC driven by the wind, and on the intensity of the current driven by the imposed sea water runoff. While the anthropogenic project concerns sea water runoff in the range of $4-20 \mathrm{~m}^{3} / \mathrm{s}$, it was decided to start to evaluate this risk of downstream pollution even in the case of moderate sea water runoffs. Different model scenarios are considered. The first scenarios, without wind, are devoted to the simulation of reopening by considering two small values of this sea water runoffs. The other scenarios are devoted to the wind effect in the case of the two dominant winds: N-NW and S-SE, whose directions are almost perpendicular to the Rove channel.

\section{Site description}

The Rove tunnel is a canal tunnel in the South of France, opened in 1927 and closed in 1963 after a section collapsed. As a part of the Canal de Marseille to Rhone, it used to connect the Etang de Berre in the north with l'Estaque in the south, hosting a part of Marseille's harbour. This tunnel is $7.120 \mathrm{~m}$ long, and is $22 \mathrm{~m}$ wide and $15 \mathrm{~m}$ high, with a water depth of $4 \mathrm{~m}$. The Rove channel, from Rove tunnel to EB, is $7.2 \mathrm{~km}$ long, the width varies in the range of $21 \mathrm{~m}-120 \mathrm{~m}$ (with a mean value of 70 $\mathrm{m}$ ). The nominal depth is $4.3 \mathrm{~m}$. So, the volume of water is about 2 millions of $\mathrm{m}^{3}$.

As mentioned at the beginning, it exists a project, since more than twenty years, to pump marine water (at $S=38 \mathrm{PSU}$ ) from the Bay of Marseille, to create a flow in this long channel, with a given flow rate in the range $1-20 \mathrm{~m}^{3} / \mathrm{s}$. This project is controversial concerning the mass flow rate to be pumped, and the risk of transport of polluted sediments which was not carefully evaluated up to now as a function of this flow rate.

At the other end, the water pushed in the Rove channel by the pumping device will enter in EB, a very wide lagoon, where we can assume that the salinity will remain constant $(S=20 \mathrm{PSU}$ ), despite the flow of higher salinity arriving from the Rove channel. EB is connected with Mediterranean sea in the Gulf of Fos (as shown on the top right of Fig. 1), through another channel (called Caronte).

It addition, the Rove channel receives fresh water from a waste treatment plant (called Palun) with a mean mass flow rate $Q_{0}=0.25 \mathrm{~m}^{3}$ / s.

As we can see in Fig. 2, the Rove channel is connected to four basins along the southern bank, and involves two enlargements along the northern bank: one near EB and another in front of Palun plant.

Another important feature of this site, is the occurrence of very frequent winds, in particular in two dominant directions: N-NW and SSE. For such winds, the specific areas mentioned here above have to be considered as they offer long fetch lengths.

As mentioned at the beginning, in the perspective to use a pumping system in the Rove tunnel, an experimental investigation has been realized by IDRA (2011). This work concerns in particular the composition of the bottom sediments at different places along the Rove channel

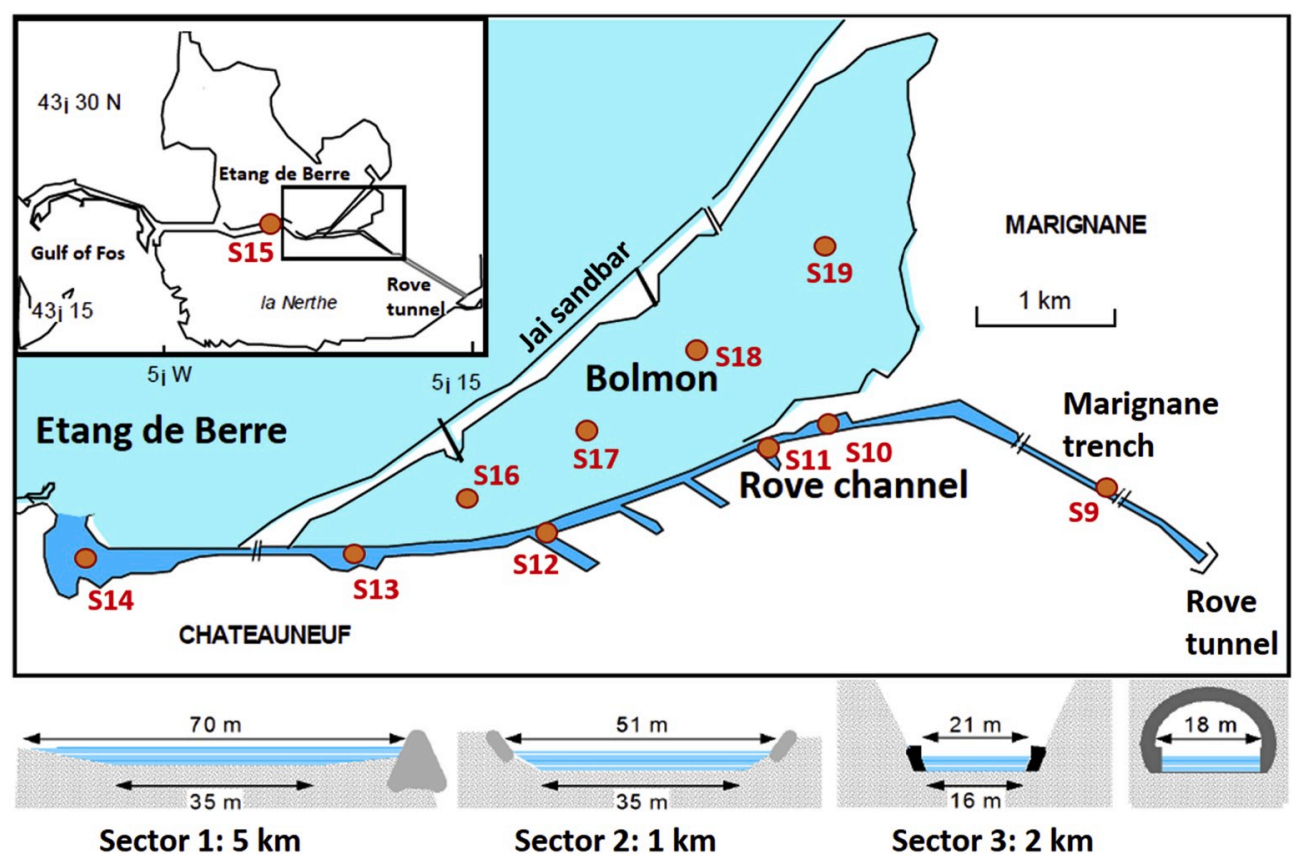

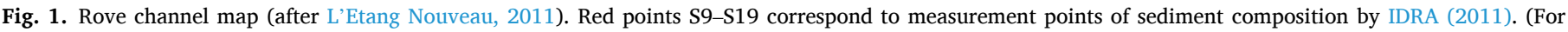
interpretation of the references to colour in this figure legend, the reader is referred to the Web version of this article.) 


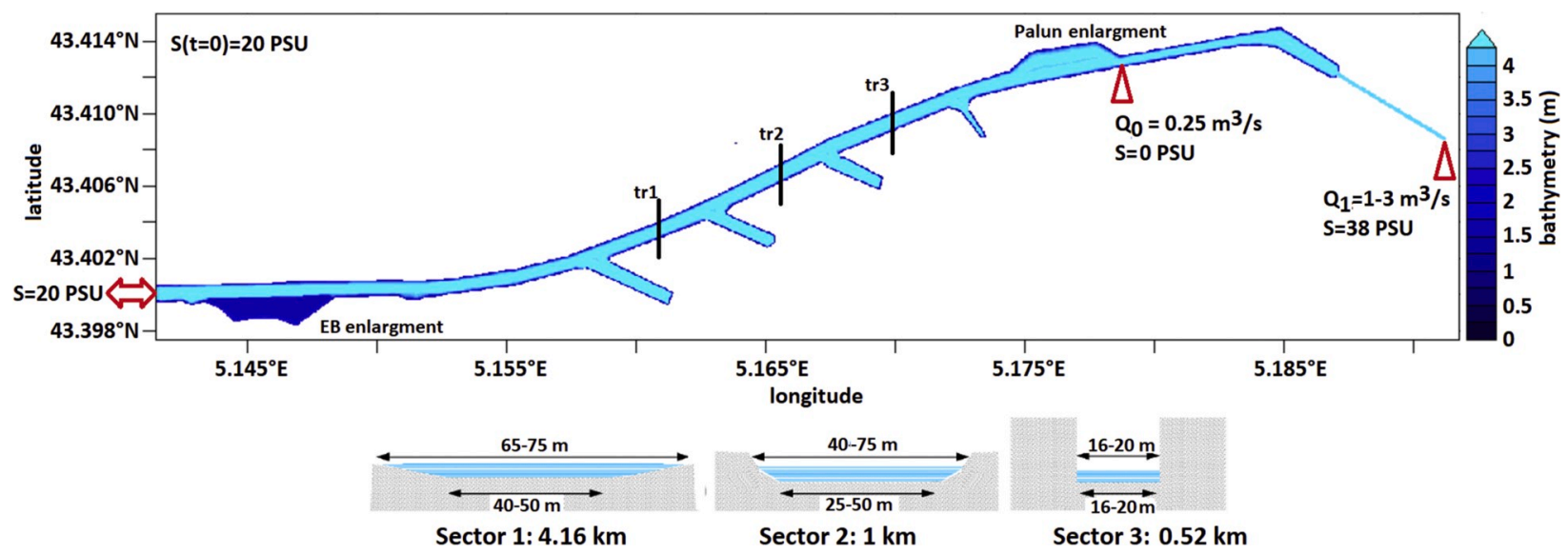

Fig. 2. Rove channel map used for numerical modelling.

(granulometry and contaminants).

Sediment composition in the Rove channel has been carefully measured by IDRA (2011), in terms of $\%$ fraction $<2 \mathrm{~mm}$, during periods without wind, in several stations (see their Tab. 6a). These authors found that the bottom sediment is mainly composed of silt with grain diameters, $d$, ranging from $2 \mu \mathrm{m}$ to $63 \mu \mathrm{m}$. They devoted special attention to the sediment sampling, as a function of the sampling depth. They isolated three sedimentary layers for their analysis:

— strata 1 (11): non consolidated silt $(2 \mathrm{~cm})$;

- strata 2 (12): superficial silt in way of consolidation $(3 \mathrm{~cm})$;

— strata 3 (13): consolidated silt (under layer 2; several cms).

Our Table 1 presents the sediment composition in these three strata at each of the five stations (S9 to S13), and then, a mean \% value for these five stations, which will be used for the present BSS numerical simulation all along the Rove channel.

The correspondence between sedimentary categories and granulometry ranges is presented in Table 2.

The composition shown in Table 1, with $79 \%$ of silt and $5.5 \%$ of clays, indicates that the bottom sediment is mainly cohesive. And, it is known that the fine particles in cohesive sediments are subject to binding forces (attraction and repulsion) which are even more important, as the ratio surface over volume is larger; i.e., when the particles are fine $(<63 \mu \mathrm{m})$.

This fraction of fine sediments is the one that preferentially fix the contaminants.

After IDRA (2011), the Rove channel presents the characteristics of a very confined media, with highly contaminated sediments, in particular in the upstream part of the channel. The physico-chemical analysis of bottom sediments provided by IDRA (2011) concerns the concentration of the following contaminants:

— inorganic: $\mathrm{Ca}, \mathrm{Cu}, \mathrm{Hg}, \mathrm{Pb}$ and $\mathrm{Zn}$

Table 1

Sediment composition in Rove channel in terms of \% Fract $<2 \mathrm{~mm}$; mean \% value of the three layers at the stations S9-13 obtained by IDRA (2011), and a mean $\%$ value for the five stations.

\begin{tabular}{lllllll}
\hline fraction & S9 & S10 & S11 & S12 & S13 & Mean S9-S13 \\
\hline$<500 \mu \mathrm{m}$ & 0,4 & 0,0 & 1,8 & 0,0 & 0,0 & 0,4 \\
$<250 \mu \mathrm{m}$ & 3,8 & 2,4 & 4,7 & 2,7 & 3,0 & 3,3 \\
$<125 \mu \mathrm{m}$ & 13,4 & 8,2 & 17,0 & 10,5 & 10,2 & 11,9 \\
$<63 \mu \mathrm{m}$ & 75,9 & 81,1 & 72,3 & 81,9 & 82,3 & 78,7 \\
$<2 \mu \mathrm{m}$ & 6,5 & 8,3 & 3,4 & 4,9 & 4,5 & 5,5 \\
\hline
\end{tabular}

Table 2

Sedimentary categories vs granulometry ranges.

\begin{tabular}{ll}
\hline sedimentary categories & granulometry ranges \\
\hline Gravels & $\mathrm{d}>2 \mathrm{~mm}$ \\
Sands & $63 \mu \mathrm{m}<\mathrm{d}<2 \mathrm{~mm}$ \\
Silts & $2 \mu \mathrm{m}<\mathrm{d}<63 \mu \mathrm{m}$ \\
Clays & $\mathrm{d}<2 \mu \mathrm{m}$ \\
\hline
\end{tabular}

- organic: PAH (Fluoranthene and Benzo(a)pyrene), PCB (CB 153) and TBT.

Their physico-chemical analysis, presented in their Tables $6 \mathrm{a}$ and $6 \mathrm{~b}$ shows that in the Northern sector of the Rove tunnel, the contamination is confirmed in $\mathrm{Cd}, \mathrm{Hg}$, As, PAH, PCB and TBT, and this contamination is maintained in the Rove channel in $\mathrm{Cd}, \mathrm{Hg}$ and PCB.

The risk associated to these sediments is presented in their Tab. 7a.

Additionally, these Authors showed that ecotoxicity is very strong in Rove tunnel (HCT and Cd) and in Rove channel. And so, an increase of the mass flow rate in the Rove channel would increase the risk of resuspension and transport of polluted particles; these particles having a stronger impact on the local and adjacent ecosystems. Indeed, anthropogenic organic contaminants and metals transported with these particles are considered as a severe threat to health.

Anyway, it is important to estimate the risk of the transport of such toxic particles towards adjacent hydrosystems (Etang de Berre and Bolmon lagoon). Indeed, these lagoons themselves already suffer from a high anthropogenic pressures since the last century due to many complex reasons (Alekseenko and Roux, 2019a,b). Remediation efforts are being made to improve the water quality and restore these ecosystems from year to year without a stable success. Therefore, an additional contamination to these ecosystems is strongly undesired. In the case of the Bolmon lagoon, hydric exchanges with the Rove channel could be easily controlled by the narrow windows (of 1-2 m width) separating these two systems, whereas EB lagoon window is much wider (with a clearance width of $80 \mathrm{~m}$ ) permitting the entrance of the contaminated particles carried by the Rove channel.

\section{Modeling and numerical simulation (different scenarios)}

The present study is realized with MARS3D (Model for Applications at Regional Scales). This 3D model is developed by the French Research Institute for the Exploitation of the Sea (IFREMER) for different environmental domains and a variety of applications involving a large range of time-space scales (Lazure and Dumas, 2008; Lazure et al., 2009). MARS3D contains a hydrodynamical model based on the equations 
proposed by Blumberg and Mellor (1986). It is based on the system of incompressible Reynolds Averaged Navier-Stokes equations in the classical Boussinesq approximation with the hydrostatic assumption. To follow more easily the variation of the surface elevation, a transformed vertical coordinate, $\sigma$, is used in such a way that $\sigma=0$ at the surface and $\sigma=-1$ at the bottom. Then, to better take into account the two boundary layers (at the surface, and at the bottom) a refinement of the $\sigma$ grid is used.

Here, we consider the channel bathymetry obtained by Sukhinov et al. (2007) by using a reconstruction method from the map given by Pont and Barroin (1993) from echo-sounding. Contrary to the previous works where the channel was divided in three sectors of homogeneous bathymetry (constant width and depth (Fig. 1), we used a more detailed bathymetry of some irregular areas (Fig. 2), as follows:

- sector 1: $4.16 \mathrm{kms}$ length from $5.142^{\circ} \mathrm{E}$ to $5.18^{\circ} \mathrm{E}$; width varying from 65 to $75 \mathrm{~m}$ at the surface and from 40 to $50 \mathrm{~m}$ at the bottom, maximal depth of $4.3 \mathrm{~m}$; sector 1 contains 2 trapezoidal areas (EB and Palun enlargments) and 4 rectangular basins;

- sector 2: $1 \mathrm{~km}$ length at the east after sector 1 from $5.180^{\circ} \mathrm{E}$ to $5.187^{\circ} \mathrm{E}$; width varying from 40 to 75 at the surface and from 25 to $50 \mathrm{~m}$ at the bottom, maximal depth of $4.3 \mathrm{~m}$;

- sector 3: $0.52 \mathrm{~km}$ at the east after sector 2 from $5.187^{\circ} \mathrm{E}$ to $5.191^{\circ} \mathrm{E}$; width from 16 to $20 \mathrm{~m}$ constant from surface to bottom, depth of $4.3 \mathrm{~m}$.

For the present numerical modelling a uniform horizontal grid with the following number of nodes: $1400 \times 360$ (i.e., with a horizontal resolution of $4 \mathrm{~m}$ ) and non-uniform vertical grid with 24 layers over vertical are used.

Such a numerical model was previously used to analyze the 3D current, salinity and temperature distributions in the adjacent lagoons Etang de Berre and Bolmon. It was carefully validated by comparison with daily observations of the vertical salinity and temperature profiles at three mooring stations, during one year (Alekseenko et al., 2017, Alekseenko and Roux, 2018).

Different scenarios will be analyzed for the two main research directions considered in the present paper: (a) salinity variation induced by an inflow of marine water (pumped through the Rove tunnel), and (b) bottom shear stress vs strong winds.

The numerical model concerns the $3 \mathrm{D}$ currents due to several dynamical forcings. In the next section (without wind effect), the model account for the micro-tide propagation from EB, the brackish water inflow from EB (eq. (1), $S=20$ PSU), the marine water inflow through the Rove tunnel $\left(Q_{1}\right.$ of varied runoff from 1 to $3 \mathrm{~m}^{3} / \mathrm{s}$ and $\left.\mathrm{S}=38 \mathrm{PSU}\right)$, the baroclinic pressure gradient created by freshwater runoff from the Palun wastewater $\left(Q_{0}\right.$ of $0.25 \mathrm{~m}^{3} / \mathrm{s}$ and $\left.\mathrm{S}=0 \mathrm{PSU}\right)$. The model also includes the bottom shear stress which depends on the bottom roughness, $z_{0}$.

Then, the wind effect is taken into account, classically, through a shear stress created at the surface by the wind.

\subsection{Micro-tidal conditions}

At its western exit, the Rove channel water is mainly connected to the Etang de Berre (which was studied by Alekseenko and Roux, 2019b), and partly to the Caronte channel which reaches the Mediterranean sea (Gulf of Fos). So, the Rove channel is subject to micro-tide. The tide amplitude at the entrance of the Caronte channel is about of about 30 $\mathrm{cm}$. Then, this amplitude decreases all the long of the Caronte channel ( $8 \mathrm{kms}$ ) to reach about $5 \mathrm{~cm}$ at the junction of the Caronte channel and the Rove channel in the Etang de Berre (according to Ramade, 1997).

$\eta(t)=0.05 \cos \left(2 \pi\left(t-t_{0}\right) / T\right)$,

where $t_{0}$ denotes the initial time of computation, $T$ is the tidal period (about $44714 \mathrm{~s}$ or $12 \mathrm{~h} 25 \mathrm{~min}$ ).

\subsection{Wind forcing conditions}

The weather database (average daily wind speed at $10 \mathrm{~m}$ ) provided by SOGREAH (2003) for the ten-years period 1992-2001 is used as in our previous paper concerning a very close area (Alekseenko and Roux, 2019b). It gives the mean annual frequency of wind speeds of $21 \mathrm{~m} / \mathrm{s}$ and $11 \mathrm{~m} / \mathrm{s}$, in 16 directions. The dominant winds direction is $\mathrm{N}-\mathrm{NW}$, and the wind speed exceeds $11 \mathrm{~m} / \mathrm{s}$ for over 102 days per year. In the present work, we will consider two wind speeds (10 and $20 \mathrm{~m} / \mathrm{s}$ ) in each of the two dominant wind directions (N-NW and S-SE).

\subsection{Boundary and initial conditions}

The model involves the horizontal components of the shear stress at the surface and the friction at the bottom. We use the following laws:

- for the surface stress components $\left(\tau_{s, x}, \tau_{s, y}\right)$

$\left(\tau_{s, x}, \tau_{s, y}\right)=\rho_{a} C d_{s} \underline{V}_{10}\left(U_{10}, V_{10}\right)$,

where $\underline{V}_{10}=\left(U_{10}, V_{10}\right)$ is the wind velocity $10 \mathrm{~m}$ above surface, $\rho_{a}=$ $1.25 \mathrm{~kg} / \mathrm{m}^{3}$ is the air density, $C d_{s}$ is the surface drag coefficient which depends on the wind speed and the surface roughness (Young, 1999; $C d_{s}=2 \cdot 10^{-3}$ for the wind speed of $10 \mathrm{~m} / \mathrm{s}$ and $C d_{s}=3 \cdot 2 \cdot 10^{-3}$ for the wind speed of $20 \mathrm{~m} / \mathrm{s}$ ).

- for the bottom stress components $\left(\tau_{b, x}, \tau_{b, y}\right)$

$\left(\tau_{b, x}, \tau_{b, y}\right)=\rho_{0} C d_{b} \underline{V}(U, V)$

with

$$
C d_{b}=\left(\kappa / \ln \left(\frac{z+H+z_{0}}{z_{0}}\right)\right)^{2},
$$

where $\underline{V}$ is the velocity vector with horizontal components $(U, V), C d_{b}$ is the bottom drag coefficient, $\kappa=0.4$ is the Von Karman constant, $\rho_{0}$ is the reference density $\left(\rho_{0}=1015.27 \mathrm{~kg} / \mathrm{m}^{3}\right), z_{0}$ is the bottom roughness which is connected to the grain size of the bottom sediments. According to Dufois and Le Hir (2015), we use the following relationship for $z_{0}$ (with $d$ varying from 0.6 to $60 \mu \mathrm{m}$ ):

$z_{0}=2.5 d / 30$

At the surface $(\sigma=0)$, temperature and salinity boundary conditions are:

$\rho_{0} \nu_{H}\left(\frac{\partial T}{\partial \sigma}, \frac{\partial S}{\partial \sigma}\right)=\left(Q_{T} / C_{p}, 0\right)$,

where $\nu_{H}$ is the vertical eddy viscosity, $Q_{T}$ - the heat flux at the air-sea interface and $C_{p}$ - specific heat of air at constant pressure, $C_{p}=1004$ $\mathrm{J} / \mathrm{kg} / \mathrm{K}$.

At the bottom $(\sigma=-1)$, boundary conditions for $T$ and $S$ are:

$\rho_{0} \nu_{H}\left(\frac{\partial T}{\partial \sigma}, \frac{\partial S}{\partial \sigma}\right)=(0,0)$,

Salinity at the open boundary connecting the Rove channel with the Etang de Berre is fixed to 20 PSU. Initial conditions for velocity and salinity fields of each scenario are presented in Table 3.

In addition, we neglect the ocean atmosphere interaction (such as latent heat flux, evaporation, solar radiation, etc.) and we assume that the temperature does not play an essential role on the wind-generated current and salinity distribution. So, the numerical simulation is realized for a constant temperature $\left(T=10^{\circ} \mathrm{C}\right)$ and for $Q_{T}=0$. 
Table 3

Modelled scenarios

\begin{tabular}{|c|c|c|c|c|c|}
\hline Scenario & init. condition & wind forcing & tidal forcing & seawater inflow $Q_{1}$ & sediment grain size $d$ \\
\hline SC0 & $\mathrm{V}=0, \mathrm{~S}=20 \mathrm{PSU}$ & no wind & no tide & $3 \mathrm{~m}^{3} / \mathrm{s}$ & $60 \mu \mathrm{m}$ \\
\hline SC1B & $\mathrm{V}=0, \mathrm{~S}=20 \mathrm{PSU}$ & no wind & micro-tide & $3 \mathrm{~m}^{3} / \mathrm{s}$ & $60 \mu \mathrm{m}$ \\
\hline SC1C & $\mathrm{V}=0, \mathrm{~S}=20 \mathrm{PSU}$ & no wind & micro-tide & $1 \mathrm{~m}^{3} / \mathrm{s}$ & $60 \mu \mathrm{m}$ \\
\hline SC2A & $\mathrm{V}, \mathrm{S}$ from end of SC1B & $\mathrm{N}-\mathrm{NW}$ wind of $20 \mathrm{~m} / \mathrm{s}$ & micro-tide & $3 \mathrm{~m}^{3} / \mathrm{s}$ & $60 \mu \mathrm{m}$ \\
\hline SC2B & $\mathrm{V}, \mathrm{S}$ from end of SC1B & $\mathrm{N}-\mathrm{NW}$ wind of $10 \mathrm{~m} / \mathrm{s}$ & micro-tide & $3 \mathrm{~m}^{3} / \mathrm{s}$ & $60 \mu \mathrm{m}$ \\
\hline SC3A & $\mathrm{V}, \mathrm{S}$ from end of SC1B & $\mathrm{S}$-SE wind of $20 \mathrm{~m} / \mathrm{s}$ & micro-tide & $3 \mathrm{~m}^{3} / \mathrm{s}$ & $60 \mu \mathrm{m}$ \\
\hline SC3B & $\mathrm{V}, \mathrm{S}$ from end of SC1B & S-SE wind of $10 \mathrm{~m} / \mathrm{s}$ & micro-tide & $3 \mathrm{~m}^{3} / \mathrm{s}$ & $60 \mu \mathrm{m}$ \\
\hline SC4A & $\mathrm{V}, \mathrm{S}$ from end of SC1B & $\mathrm{N}-\mathrm{NW}$ wind of $20 \mathrm{~m} / \mathrm{s}$ & micro-tide & $3 \mathrm{~m}^{3} / \mathrm{s}$ & $6 \mu \mathrm{m}$ \\
\hline SC4B & $\mathrm{V}, \mathrm{S}$ from end of SC1B & $\mathrm{N}-\mathrm{NW}$ wind of $10 \mathrm{~m} / \mathrm{s}$ & micro-tide & $3 \mathrm{~m}^{3} / \mathrm{s}$ & $0.6 \mu \mathrm{m}$ \\
\hline
\end{tabular}

\subsection{Description of scenarios}

In order to study the impact of different forcings and properties (tide, wind, seawater inflow, sediment grain size) on the salinity and BSS distributions various scenarios have been simulated (Table 3).

\section{Salinity results}

All our computational simulations are performed with the following boundary conditions for the salinity: $\mathrm{S}=38 \mathrm{PSU}$ at the entrance of our computational domain and $\mathrm{S}=20 \mathrm{PSU}$ at the exit of this domain. We assume zero salinity gradient at the bottom and at the surface.

Our computational simulations have been firstly performed in the case without wind for the three following scenarios, SC0, SC1B, SC1C (Table 3).

Here, the hydrodynamics is governed by two main driving mechanisms: forced convection due to the imposed runoff at the entrance of the computational domain and the solutal convection due to the imposed salinity difference between the entrance and the exit of this domain.

The evolution of surface salinity all along the Rove channel is shown in Fig. 3a for the scenario SC1B, with micro-tide and a runoff of $3 \mathrm{~m}^{3} / \mathrm{s}$, after 24 days. Just for information, in Fig. 3b, we compare this evolution with that obtained in the model case SCO without tide. We can see that the influence of micro-tide is not substantial. Nevertheless all the present numerical simulations are performed with the same micro-tide condition (eq. (1)). Then, the runoff effect (for $Q_{1}=1 \mathrm{~m}^{3} / \mathrm{s}$ and $Q_{1}=3 \mathrm{~m}^{3} / \mathrm{s}$ ) is shown in Fig. 3c.

Wind effect on salinity in the water column has been analyzed for two wind speeds $(10 \mathrm{~m} / \mathrm{s}$ and $20 \mathrm{~m} / \mathrm{s})$. A quasi-permanent regime is obtained in about two days of simulation. The vertical profiles of salinity have been analyzed along three selected transects tr 1 , tr 2 and tr 3 in the median part of the channel (shown in Fig. 2). For each transect, the mean value (along the y coordinate) of these profiles is given in Fig. 4 for the two wind directions N-NW and S-SE and the two wind speeds. A

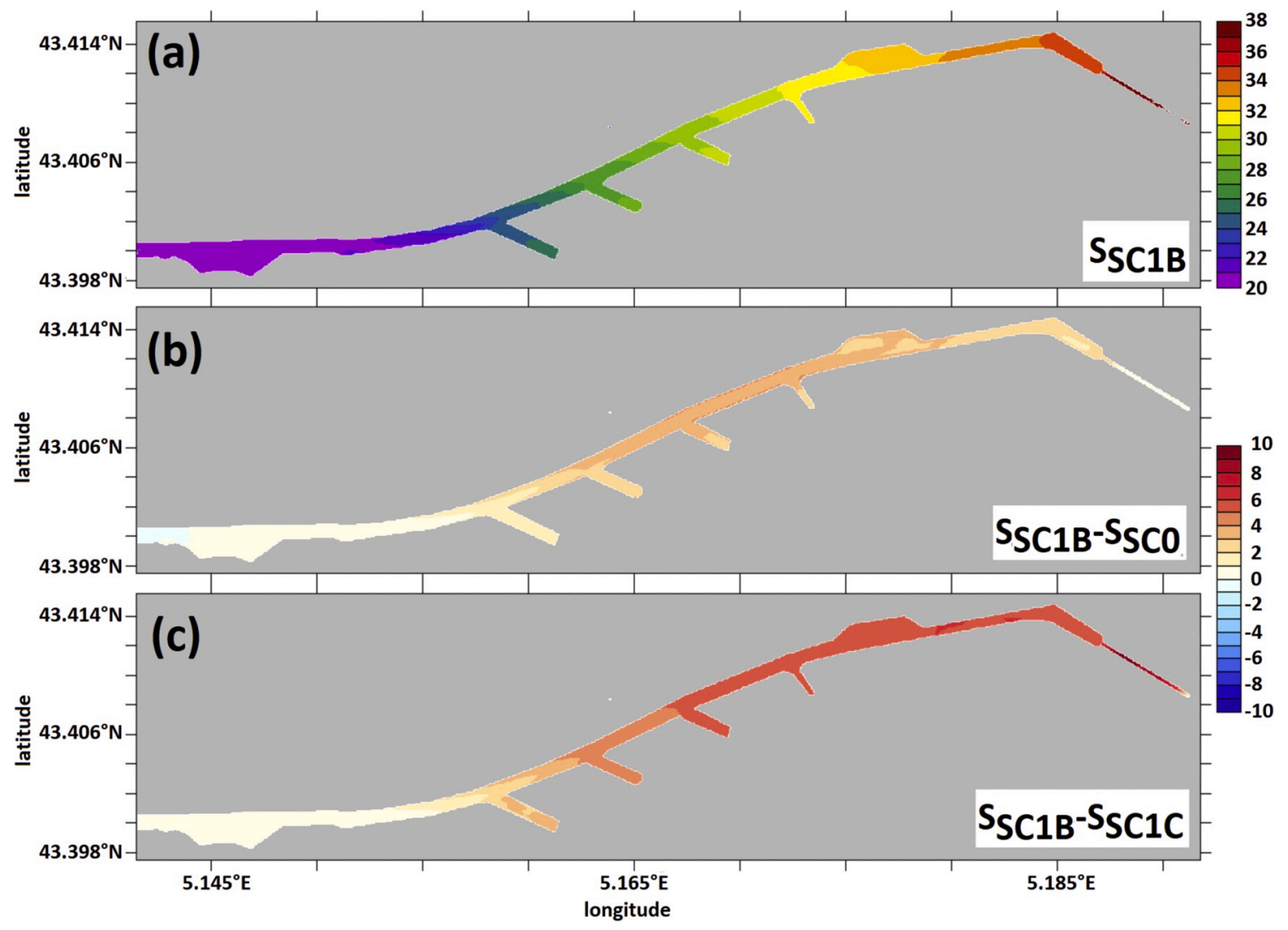

Fig. 3. (a) surface salinity along the Rove channel for SC1B (with tide and $Q_{1}=3 \mathrm{~m}^{3} / \mathrm{s}$ ) (b) impact of tide on surface salinity; salinity difference between scenarios SC0 and SC1B; (c) impact of runoff on surface salinity; salinity difference between scenarios SC1B and SC1C (with tide and $Q_{1}=1 \mathrm{~m}^{3} / \mathrm{s}$ ). 


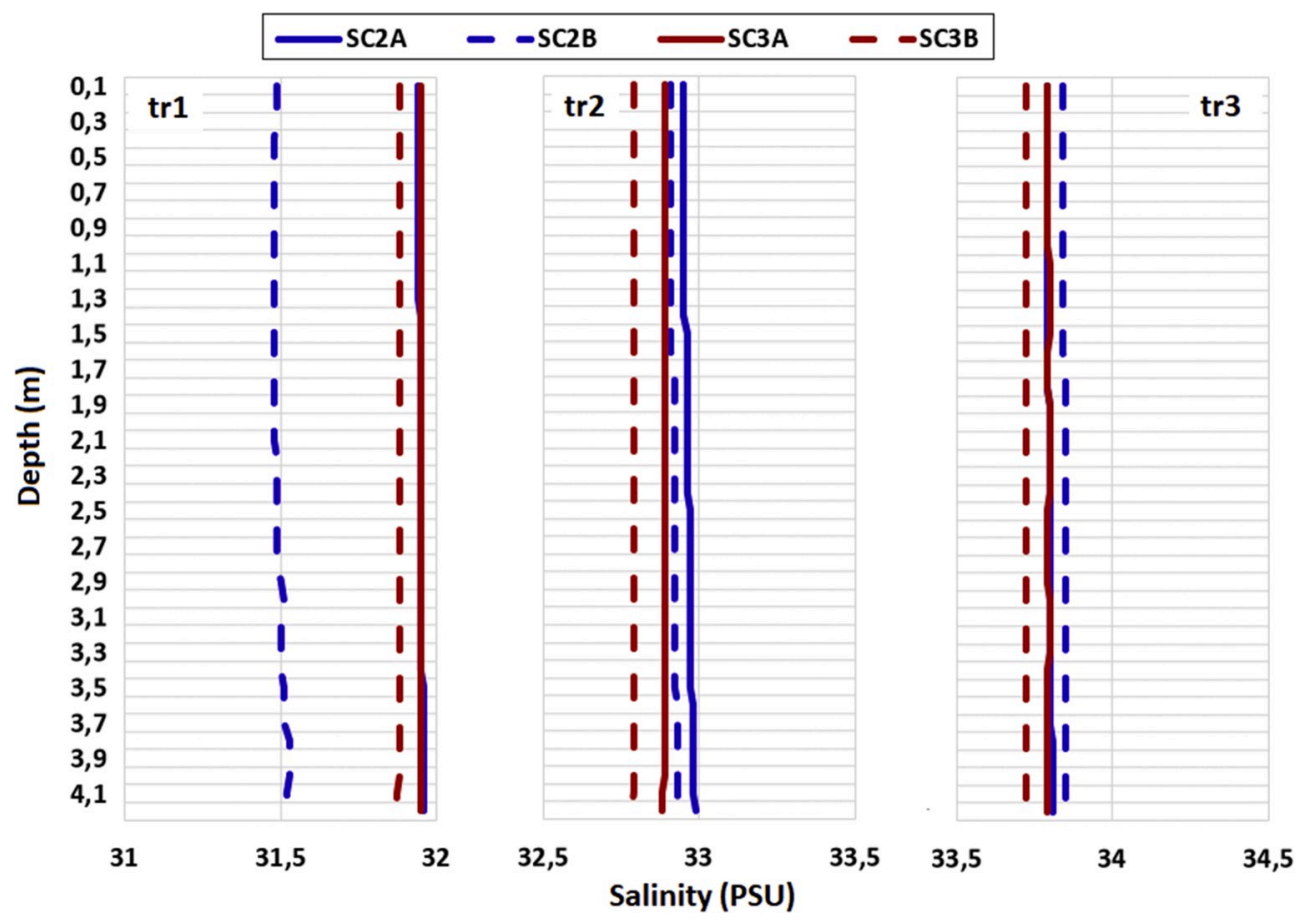

Fig. 4. Wind effect $(10 \mathrm{~m} / \mathrm{s}$ and $20 \mathrm{~m} / \mathrm{s})$ averaged along significant transects in Rove channel for $Q_{1}=3 \mathrm{~m}^{3} / \mathrm{s}$, at the last time step; schematic position of tr1-tr3 is shown on Fig. 2.

complete salinity mixing from the bottom to the surface is observed, even for a wind of $10 \mathrm{~m} / \mathrm{s}$. The salinity level is slightly larger for larger wind speed.

A final comparison of the evolution of the vertical profiles of salinity is given in Fig. 5 for the largest forcings, i.e., wind speed of $20 \mathrm{~m} / \mathrm{s}$ and $Q_{1}=3 \mathrm{~m}^{3} / \mathrm{s}$. It summarizes the following scenarios: SC2A (N-NW wind), SC3A (S-SE wind), SC1B (no wind).

For these three transects, the vertical profiles of salinity for N-NW and S-SE winds are almost superposed. We can observe a decreasing of salinity along the downstream direction, as it is expected.

On the contrary, for the scenario without wind (SC1B), the profile shows an haline stratification with a substantial vertical salinity gradient near the surface. This gradient is due to a reverse flow at the surface which tends to push EB water upstream.

To better understand the evolution of the salinity all along the Rove channel for a wind speed of $20 \mathrm{~m} / \mathrm{s}$, the surface salinity is presented in

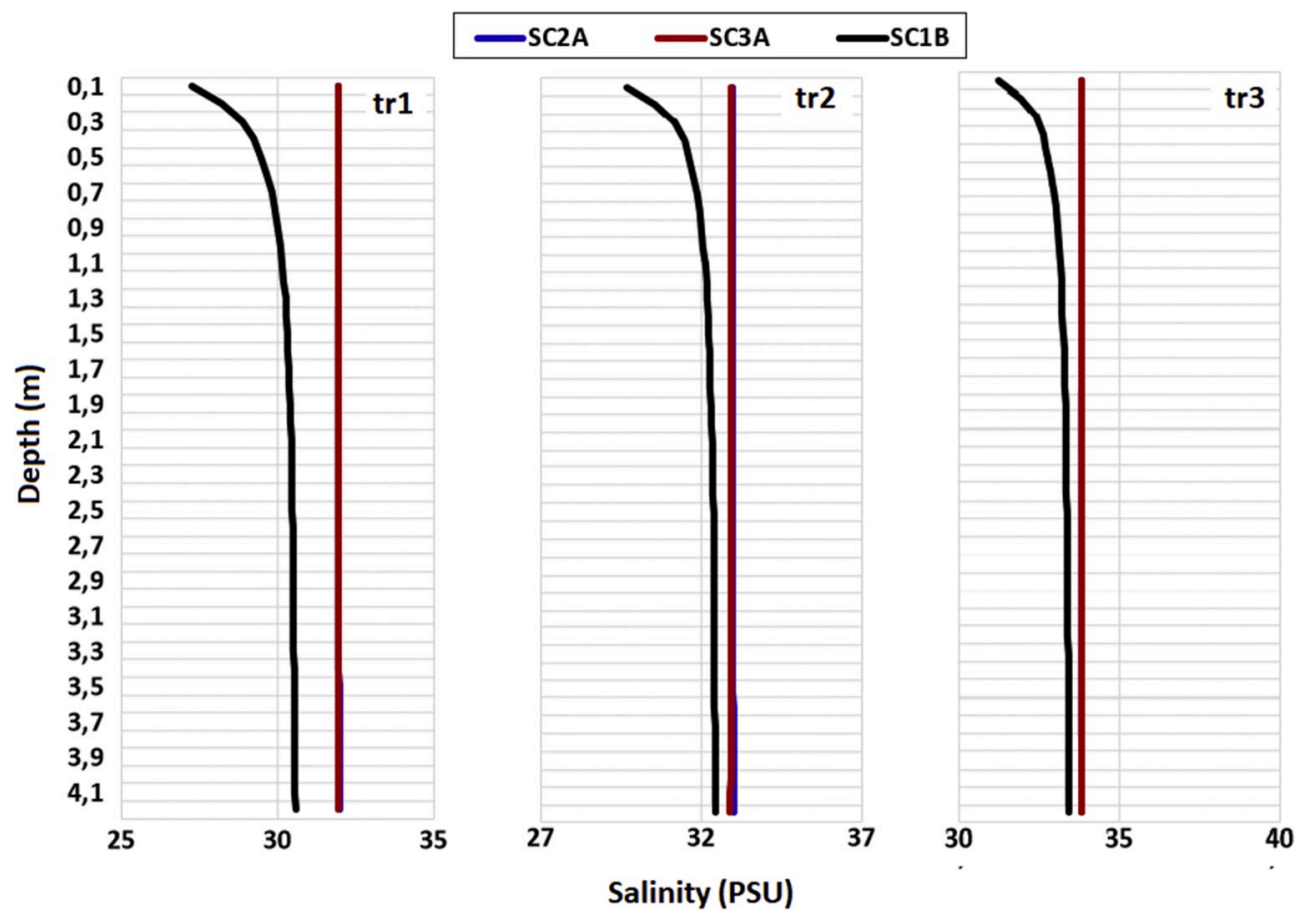

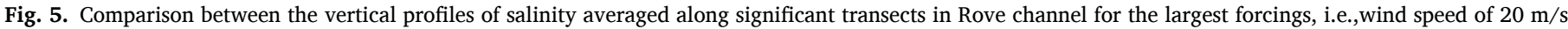
and $Q_{1}=3 \mathrm{~m}^{3} / \mathrm{s}$, at the last time step; schematic position of tr1-tr3 is shown on Fig. 2. 


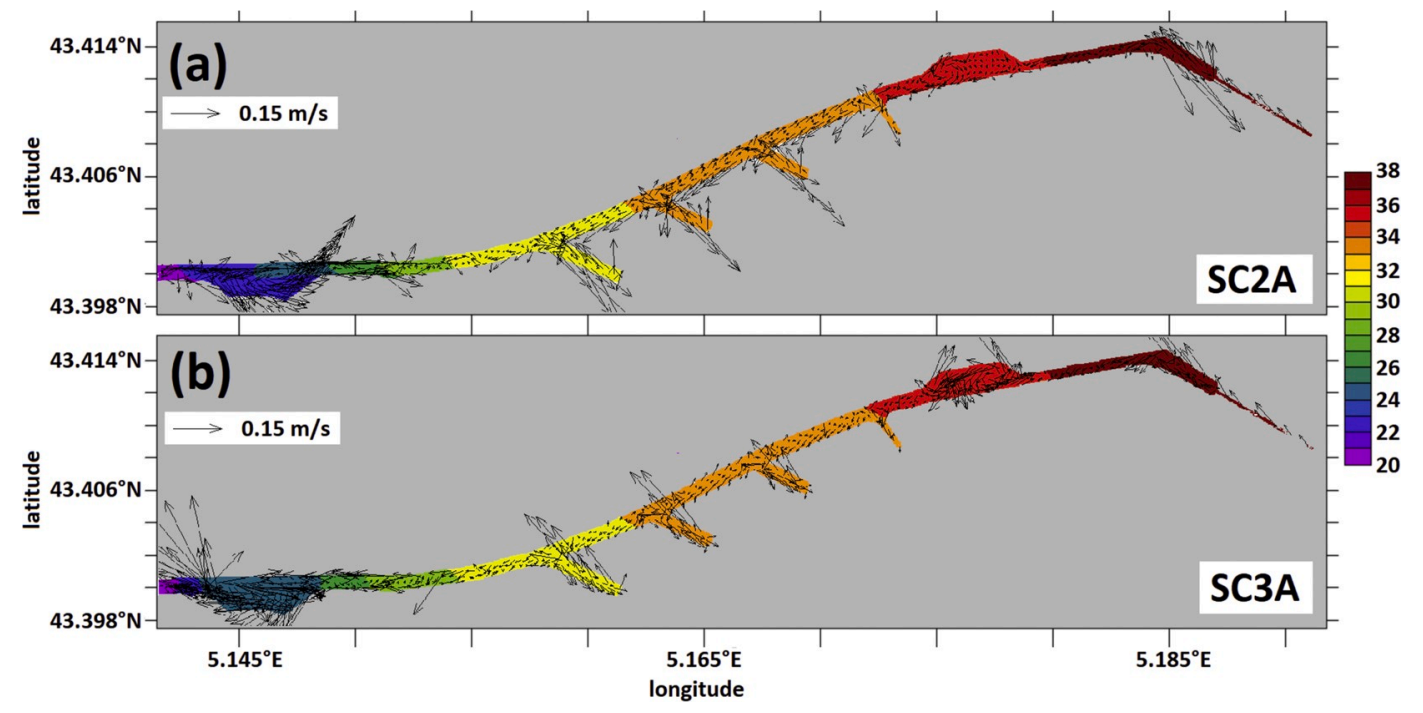

Fig. 6. Surface salinity and barotropic component of the current for a wind speed of $20 \mathrm{~m} / \mathrm{s}$ and for $Q_{1}=3 \mathrm{~m}^{3} / \mathrm{s}$; (a) for N-NW direction, (b) for S-SE direction.

Fig. 6 in addition with the barotropic component of the current. When comparing these two patterns with those shown for SC1B in Fig. 3, we can conclude that strong winds $(20 \mathrm{~m} / \mathrm{s})$ generate substantially higher surface salinity. This is consistent with the results shown in Fig. 5.

In addition, this Fig. 6 shows a very complex evolution of the barotropic component of the current, due to the bathymetric irregularities (2 trapezoidal enlargements, and 4 basins along the southern bank of the channel) and the orientation of the entrance sector which offer large fetch lengths. Along the northern bank of the channel there is an upstream barotropic current. It flows for a long distance for the N-NW wind. It can be seen also for the S-SE wind, but slower.

\section{Bottom shear stress}

In this section we analyze the evolution of the bottom shear stress (BSS $=\sqrt{\tau_{b, x}^{2}+\tau_{b, y}^{2}}$ ) which is crucial to predict the erosion conditions for a given bottom granulometry. According to the composition of the bottom sediments given in Table 1 , most of the calculations are performed for the bottom roughness $z_{0}$ of $5 \mu \mathrm{m}$. The calculations have been performed for all the scenarios listed in Table 3. For the sake of simplicity, we discuss only the results concerning the runoff $Q_{0}=3 \mathrm{~m}^{3}$ / $\mathrm{s}$. The patterns of BSS modulus all along the Rove channel are presented in Fig. 7 for these five scenarios (SC1B, SC2A, SC2B, SC3A and SC3B). These patterns exhibit strong variations in the transverse direction across the channel, in particular for the largest wind speed. They also show that BSS reaches substantial values in the four basins; this is due to their orientation with respect to the two dominant wind directions.

In order to better calibrate this modulus, the transverse profile, BSS (y), has been determined along three transects, $\operatorname{tr} 1-\operatorname{tr} 3$ (indicated in Fig. 2), in the most regular sectors of the channel. An averaging of these three transects is shown in Fig. 7a for the scenario without wind, and in Fig. $7 \mathrm{~b}$ for the scenarios with wind, to get a rough estimation of the largest values of BSS. For the scenario without wind, BSS remains moderate all along the channel (Fig. 8a) with value not exceeding 0.015 $\mathrm{N} / \mathrm{m}^{2}$ (Fig. 7a).

For the scenarios with wind (Fig. $8 \mathrm{~b}-\mathrm{e}$ ), the patterns are much more complex in particular for the wind speed of $20 \mathrm{~m} / \mathrm{s}$ (SC2A and SC3A). This behavior is consistent with the complex patterns of the flow which is clearly illustrated in Fig. 6 with the barotropic currents in the case of wind speed of $20 \mathrm{~m} / \mathrm{s}$. For such a wind speed, BSS can reach about 0.18 $\mathrm{N} / \mathrm{m}^{2}$ (Fig. 7b), and we can see that, as expected, BSS reaches a maximum near the southern bank for the N-NW wind, and near the northern bank for S-SE wind.
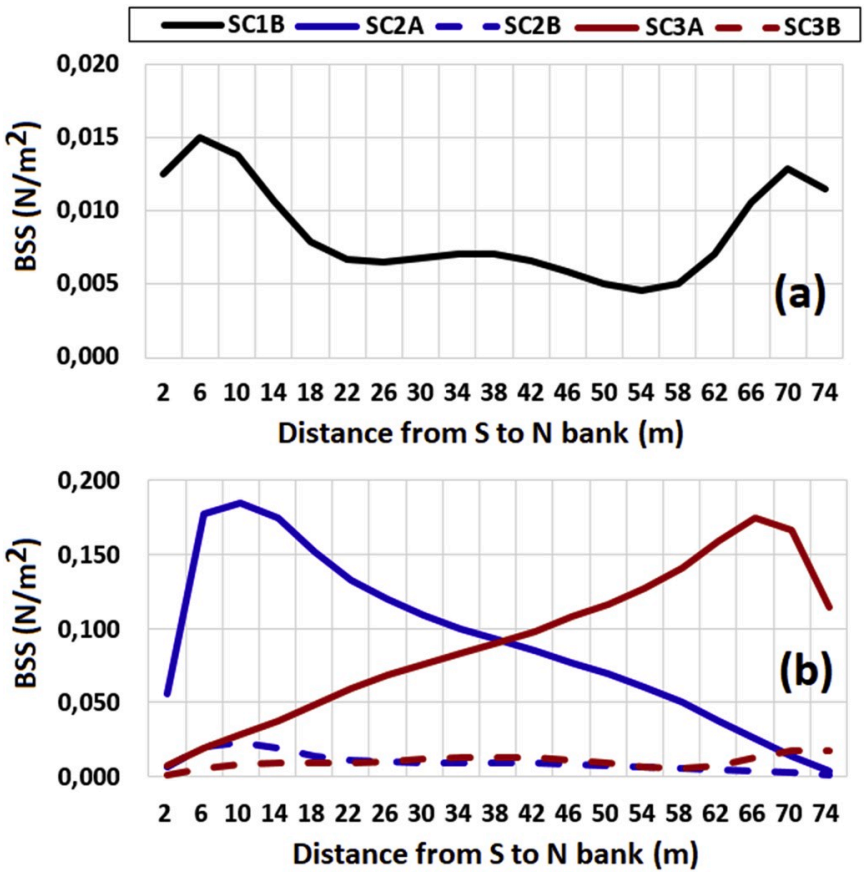

Fig. 7. BSS along significant transects in Rove channel for different scenarios: (a)SC1B and (b) SC2A; SC2B; SC3A and SC3B; schematic position of tr1-tr3 is shown in Fig. 2.

In the case of wind of $10 \mathrm{~m} / \mathrm{s}$, as for the wind of $20 \mathrm{~m} / \mathrm{s}, B S S$ reaches a maximum near the southern bank for the N-NW wind, and near the northern bank for S-SE wind. Here, BSS can reach $0.03 \mathrm{~N} / \mathrm{m}^{2}$ (Fig. $7 \mathrm{~b}$ ), i. e., about twice the value corresponding to the scenario SC1B without wind (Fig. 7a).

In order to evaluate the maximum achievable BSS along the Rove channel (in the context of erosion risk), the numerical results in the two trapezoidal zones (EB and Palun) mentioned in Section 4 are analyzed. Larger wind-driven currents, and BSS, are expected due to larger fetch lengths, which can reach about $140 \mathrm{~m}$ and $160 \mathrm{~m}$, respectively.

The results are presented only for Palun enlargement in Fig. 9, (a) for $\mathrm{N}-\mathrm{NW}$ direction and (b) for the S-SE direction. In all cases the distance along each transect is measured in $\mathrm{m}$, with the origin at the southern bank. The surface velocity increases along each transect in the windward 

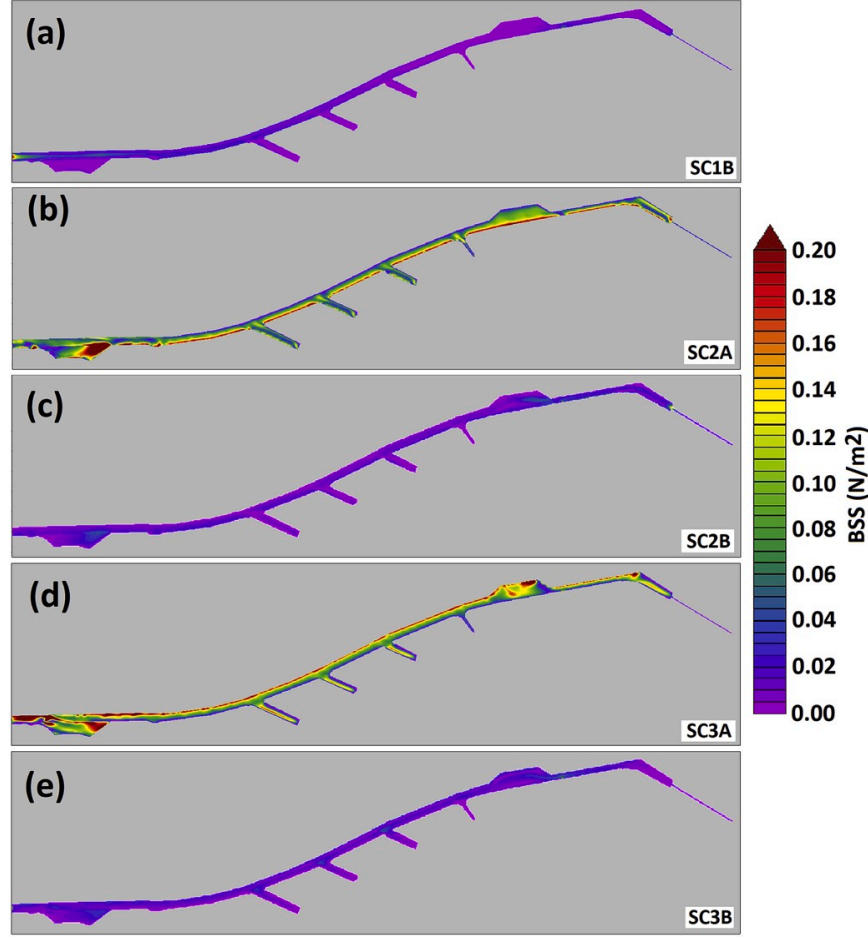

Fig. 8. BSS along the Rove channel for different scenarios: (a) SC1B; (b) SC2A; (c) SC2B; (d) SC3A and (e) SC3B.
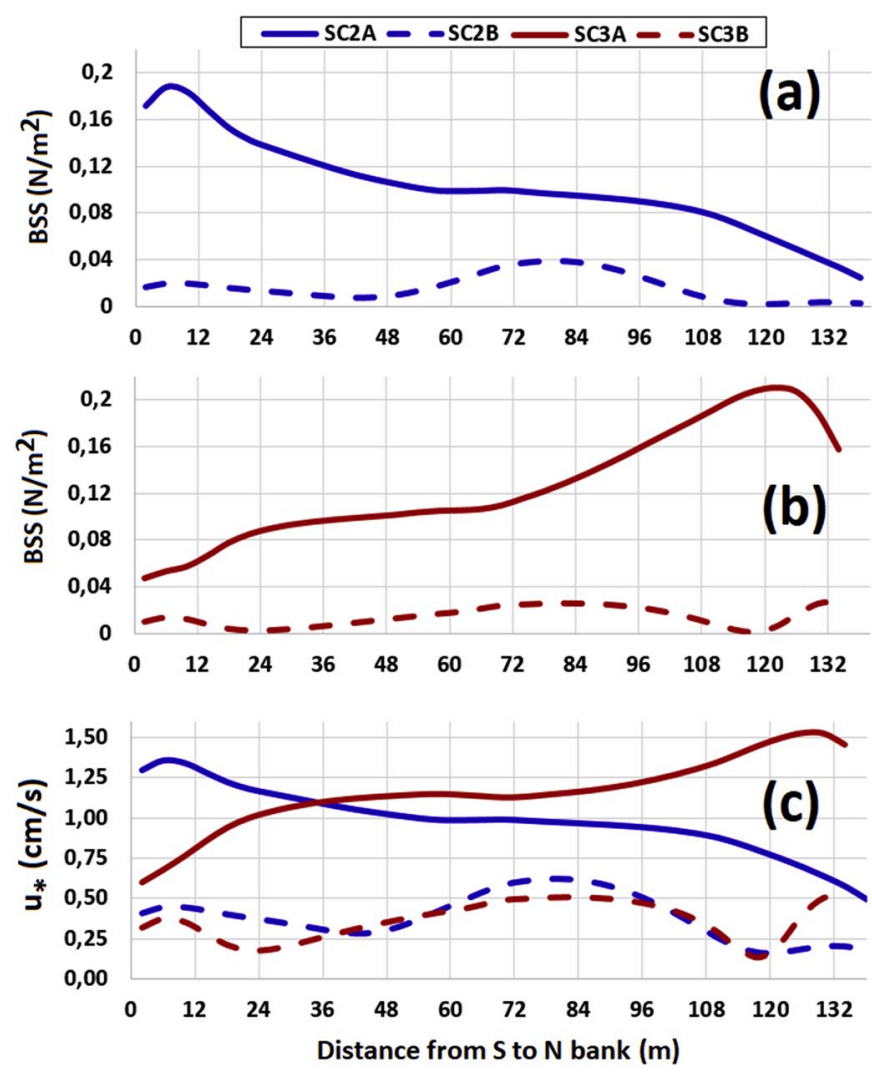

Fig. 9. BSS along transects across Palun enlargement; (a) N-NW and (b) S-SE, and (c) bed shear velocity $u *$ for two wind speeds: $20 \mathrm{~m} / \mathrm{s}$ and $10 \mathrm{~m} / \mathrm{s}$. direction: i.e., from the northern bank of the channel for the N-NW wind (and the southern bank for the S-SE bank). When reaching the opposite bank, the surface flow is plunging and generates a reverse bottom current which is maximum near this bank.

For the N-NW wind of $20 \mathrm{~m} / \mathrm{s}$, BSS reaches a maximum of about 0.19 $\mathrm{N} / \mathrm{m}^{2}$ along the windward Palun transect of $140 \mathrm{~m}$ (Fig. 9a). For S-SE wind of $20 \mathrm{~m} / \mathrm{s}, B S S$ reaches a maximum of about $0.21 \mathrm{~N} / \mathrm{m}^{2}$ along the windward Palun transect of $136 \mathrm{~m}$ (Fig. 9b). For a further comparison of our results with other results measured by Carlin et al. (2016) in the similar lagunar system with muddy sediment of a similar grain size and under similar meteorogical conditions we calculated bed shear velocity using the following equation:

$u_{*}=\sqrt{B S S / \rho_{0}}$

The bed shear velocity along the Palun transect is shown on the Fig. 9c. For four scenarios the $u_{*}$ is within the range of $0.1-1.5 \mathrm{~cm} / \mathrm{s}$.

Finally, for completeness, a sensibility study has been realized for the parameter $z_{0}$ by considering two additional sub-scenarios, SC4A and SC4B, with $z_{0}=0.5 \mu \mathrm{m}$ and $0.05 \mu \mathrm{m}$, respectively, in the case of the largest wind speed. The results obtained for the N-NW wind of $20 \mathrm{~m} / \mathrm{s}$, along the windward transect across the Palun enlargement, are shown in Fig. 10. All along the transect, BSS increases when $z_{0}$ decreases. It corresponds to the expected behavior. $B S S$ can reach up to about $0.22 \mathrm{~N} / \mathrm{m}^{2}$ near the southern bank for $z_{0}=0.5 \mu \mathrm{m}$ and about $0.24 \mathrm{~N} / \mathrm{m}^{2}$ for $z_{0}=0.5$ $\mu \mathrm{m}$. It is important to know such achievable maximum of $B S S$ in order to evaluate the erosion rate which is connected to the deviation of $B S S$ with respect to the erosion threshold.

\section{Risk of erosion of bottom sediments and contaminant transport}

As it was mentioned before (Table 1), the bottom sediments in the part of the Rove channel under consideration (with about 15\% sand, $80 \%$ silt and $5 \%$ clay) are mainly cohesive. These sediments contain a large concentration of organic and inorganic contaminants as mentioned at the end of Section 2. It is known that the role of sediment in chemical pollution is tied both to the particle size of sediment, and to the amount of particulate organic carbon associated with the sediment (up to $6.7 \%$ of dry sediment in the Rove channel, after Tabs.6a-b of IDRA, 2011). The chemically active fraction of sediment is usually cited as that portion which is smaller than $63 \mu \mathrm{m}$ (silt + clay). Particle size is of primary importance due to the large surface area of very small particles. So, it is crucial to evaluate the risk of resuspension of muddy bottom sediments which will lead to the downstream transport of contaminants.

Panagiotopoulos et al. (1997) recommend, when the shear strength (i.e. threshold of movement) of natural marine sand-mud deposits has to be investigated, to consider the modelling with caution. Indeed, it would be needed to consider the type of clay minerals, $\mathrm{pH}$ and temperature of the eroding (ambient) fluid, the chemical properties of the pore and eroding fluids, internal sediment structure, degree of sediment

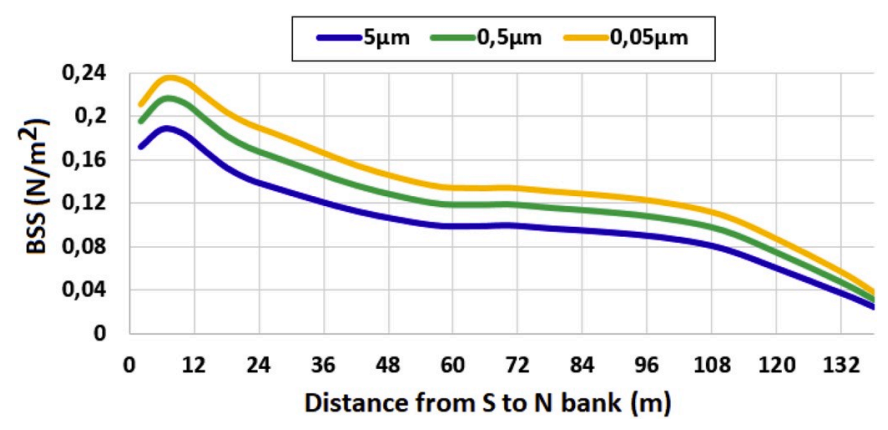

Fig. 10. Effect of bottom roughness on BSS along Palun enlargement transect, for the N-NW wind speed of $20 \mathrm{~m} / \mathrm{s}$. 
saturation and biological activity.

Accordingly, Debnath and Chaudhuri (2010) consider that not much progress has yet been made in understanding cohesive sediment erosion threshold due to the inherent physical, chemical, biological and microbiological complexity of natural cohesive sediments. But, such properties are very specific of any coastal hydro-system (lagoon or estuary), and we do not have such a detailed knowledge for the Rove channel. Further the debate of existence or nonexistence of cohesive sediment erosion threshold, and different definitions of threshold has resulted in complexity in use, interpretations and comparison of cohesive sediment threshold data.

\subsection{Erosion process}

Righetti and Lucarelli (2007), described erosion process of cohesive sediments as a multi-step entrainment phenomenon, for which different stages of sediment motion could be recognized.

- For low velocities they observed a sporadic, discontinuous motion of aggregates having a relatively small size, mainly primary particles or particle aggregates weakly bound to floc surface, as also observed by Krone (1984).

- For increasing flow velocities, a more intensive flux of primary particle aggregates was attained, coupled with sporadic entrainment of larger size aggregates.

- Further, enhancement of flow velocity produced a gradual enhancement of flocs entrainment, until an abrupt change in the erosive process took place: a sudden change not only in the quantity of eroded flocs takes place but also in their size was noticed.

More recently, Winterwerp et al. (2012) and van Rijn (2016) realized exhaustive reviews of several works devoted to transport and fate of fine, cohesive sediments, and the exchange of fine sediment between the sea bed and the water column above. They concern in particular the shear flow-induced erosion of soft cohesive sediment beds, for which they suggest to distinguish three types of erosion of muddy beds, as follows:

- floc erosion, which is the pick-up of individual particles and small scale flocs of the top layer of the bed by the turbulent vortices of the fluid flow just above the bed, and which occurs for $0.5 B S S_{c r}$ $<B S S<1.5 B S S_{c r}$ with $B S S_{c r}$ - erosion threshold stress and BSS applied time-averaged bed-shear stress;

- surface erosion for $1.5 B S S_{c r}<B S S<3 B S S_{c r}$, which is the simultaneous mobilization of several layers of particles and flocs;

- mass erosion: $B S S>3 B S S_{c r}$, which is the erosion of lumps of bed material when the applied fluid stresses are larger than the undrained soil strength of the bed.

This behavior is also confirmed by Mathew and Winterwerp (2017). As mentioned by Le Hir (2008), due to the properties of most of the clay minerals which have the particularity to possess negative surface loads, an input of cations reduce such electrical repulsion, leading to the agglomeration (flocculation) of clay particles. In estuarine sites, and in the Rove channel as well, the salinity level (due partly to the $\mathrm{Na}+$ cation) favours the flocculation.

\subsection{Risk of contaminant transport}

The risk of contaminant transport is generally associated to the flux of suspended sediment concentration (SSC), i.e., explicitly or implicitly assuming that the total erosion rate $E$ is equivalent to the resuspension rate. However, as pointed out by Debnath et al. (2007), the erosion rate (E) consists of two components, resuspension rate $(E r)$ and bed-load component $(E b)$ which refers to some portion of the eroded sediment which moves as bed load. These authors presented and discussed new field data on cohesive sediment erosion, with particular focus on partitioning the total erosion into resuspension and bed load. They analyzed the potential importance of bed load in cohesive sediment erosion, for about 30 samples of fine clay-silt-sand sediments listed in their Table 1. They found that with an increase in BSS, the relative contributions of the resuspension and bed-load component to the total erosion, $E r / E$ increases and then saturates to 1 at BSS of about $0.5 \mathrm{~N} / \mathrm{m}^{2}$ (see their Fig. 12). In addition, they show that the resuspension component decreases (or bed-load component increases) with an increase in clay content. A possible explanation of this effect may be related to a change in the clay-silt-sand network structure with an increase in the clay content: larger sediment flocs/aggregates are formed which are then detached and transported as bed load.

Amos et al. (2010) studied erosion rate of muddy sediments in several stations in Venetian nothern and southern lagoons: 13\% sands, $61 \%$ silts, $26 \%$ clays and $16 \%$ sands, $54 \%$ silts and $30 \%$ clays, respectively (see their Table 2). They pointed out the importance of the erosion rate per unit area of bed flux, $E$, which is an essential precursor to the prediction of eroded depth and the suspended sediment concentration for a given applied bed shear stress; whilst solution of the erosion threshold is often reported, the evaluation of the variation of this threshold through the process of erosion (eroded depth) is usually omitted or not estimated. The field experiments of Amos et al. (2010) showed that $E$ is changing throughout the period of a given applied shear stress. The maximum rate increases with flow speed; but the minimum rate appears constant (at $10^{-4} \mathrm{~kg} / \mathrm{m}^{2} / \mathrm{s}$ ). They also expressed $\mathrm{E}$ as a function of excess bed shear stress. Note that their sediment composition with about $85 \%$ of mud is not far from that in the Rove channel.

\subsection{Mud erosion laws}

What is important in view of the transport of contaminant by the current in the Rove channel, is to evaluate the mud erosion.

There is an abundant literature concerning erosion laws for many sorts of sediments and environmental conditions.

Perera and Wu (2016), in agreement with previous Authors, consider that it is very challenging to quantify erosion dynamics of cohesive sediments, due to the complexity of many physical, chemical, and biological processes involved. In their investigation of relationships of erosion coefficients with respect to sediment properties, they have tested an existing empirical formula to predict the erodibility coefficient when the clay percentage and dry specific weight of soil are given. Finally, by using measurement data, they suggested that the critical shear stress of cohesive soils is also related to the dry density and solid-void volume ratio.

A mud erosion law was set up by Mengual et al. (2017) for muddy estuarine sediment samples (with mud fraction higher than 70\%). Their erodimetry experiments indicate a critical shear stress for mud erosion, $B S S_{c r, m u d}$, of $0.1 \mathrm{~N} / \mathrm{m}^{2}$. In fact, according to their Fig. 4 which shows a rapid increase of $S S C$, this $B S S_{c r, m u d}$ also corresponds the onset of resuspension. By combining this $B S S_{c r \text {.mud }}$ value with the minimum erodibility parameter $E_{0, \text { mud }}$ recommended by e.g., Winterwerp (1989), i.e., $10^{-5} \mathrm{~kg} / \mathrm{m}^{2} / \mathrm{s}$, the application of the mud erosion law from their model led to good agreement between modelled erosion fluxes and those obtained in erodimetry experiments for comparable applied shear stresses. Such a lower critical stress for erosion when the mixture is muddier is opposite to trends most often published, characterized by an increase of the resistance to erosion when mud is added to sand. This low value of $B S S_{c r, m u d}$ is justified by the fact that in their environment the surficial sediment remains unconsolidated.

Wu et al. (2018) also consider that critical shear stress for erosion of pure muds is quite complex as it is affected by many factors, including bed density, mineral composition, size composition, organic material, salinity, temperature, $\mathrm{pH}$ value, and sodium absorption ratio. 
Nevertheless, among these parameters, the bed dry density was chosen in their study, because it can indicate the degree of compaction that affects the soil erodibility significantly. In addition, they found that the mud dry density, not the mixture dry density, is a direct factor affecting the erosion of sand and mud mixtures. In the past, Kothyari and Jain (2008) already pointed out the important influence of water content, clay percentage and applied bed shear stress on the initiation of motion. These last conditions well correspond to the unconsolidated muddy sediments of the present study.

\subsection{Determination of erosion threshold in the Rove channel}

To evaluate the risk of the downstream transport of the contaminated bed sediment of the Rove channel, it is needed to compare the $B S S$ values obtained in Section 5, with the erosion threshold which depends in particular of the bottom roughness parameter $z_{0}$, which can be connected to the grain-size roughness, $d$, by the relationship (5).

An evaluation of the critical bottom shear stress for the sediment mobility, $B S S_{c r}$, is proposed by Berenbrock and Tranmer (2008) for a large range of particle diameters $d$ (see their Table 7). The corresponding values for the Rove sediments, in the range $0.05 \mu \mathrm{m}<z_{0}<10 \mu \mathrm{m}$, are given in Table 4.

In Section $5, B S S$ has been determined for three values of $z_{0}$, to cover a large number of sediments which can be found in the Rove channel (from fine sand to silt and clay); namely: $z_{0}=5 \mu \mathrm{m}, 0.5 \mu \mathrm{m}$ and $0.05 \mu \mathrm{m}$ which corresponds to $d=60 \mu \mathrm{m}, 6 \mu \mathrm{m}$ and $0.6 \mu \mathrm{m}$, respectively. The values for the largest $B S S$, which are obtained for the wider enlargement (i.e., Palun), aregiven in Table 5 which is also include $B S S_{c r}$ for the corresponding $\mathrm{z}_{0}$.

So, our results show that the mobility threshold for fine sand is largely overpassed for winds of $20 \mathrm{~m} / \mathrm{s}$. For finer bed sediments (silt and clays) this threshold can be reached for winds of $10 \mathrm{~m} / \mathrm{s}$.

\subsection{Discussion}

Our results can be favorably compared with different research works devoted to resuspension of fine bed sediments in similar lagunar or estuarine shallow environments.

Concerning the sediment resuspension in a shallow micro-tidal lagoon, Carlin et al. (2016) realized detailed in situ measurements of wind speed and direction during two events of 4-5 days involving a meteorological frontal passage with strong wind. During each event (which involves three phases: prefrontal, frontal and posfrontal, resp.) they realized measurements of suspended sediment concentration (SSC) and bed shear velocity $(\mathrm{u} *)$.

- For event-1 (28-31 jan., 2013), the wind reaches speeds of about 16 $\mathrm{m} / \mathrm{s}$ (and wind-gusts up to $20 \mathrm{~m} / \mathrm{s}$ ). A relationship between wind stress and sediment resuspension is found with peaks of near-bed SSC (up to $1 \mathrm{~g} / \mathrm{l}$ ) corresponding to wind-stress peaks of about $0.6 \mathrm{~N} / \mathrm{m}^{2}$. With estimated $\mathrm{u}^{*}$ idm max of about $0.7 \mathrm{~cm} / \mathrm{s}$ and $S S C$ of $100 \mathrm{mg} / \mathrm{l}$.

- For event-2 (10-14 feb., 2013), the wind reaches speeds of about 14 $\mathrm{m} / \mathrm{s}$ (and wind-gusts up to $18 \mathrm{~m} / \mathrm{s}$ ), with peaks in near-bed SSC (up to

Table 4

Evaluation of critical BSS according to Berenbrock and Tranmer (2008).

\begin{tabular}{llll}
\hline Sediment & $d, \mathrm{~mm}$ & $z_{0}, \mathrm{~mm}$ & $B S S_{c r}, \mathrm{~N} / \mathrm{m}^{2}$ \\
\hline Fine sand & 0.120 & 0.010 & 0.144 \\
Coarse silt & 0.060 & 0.005 & 0.108 \\
Coarse silt & 0.040 & 0.0033 & 0.091 \\
Medium silt & 0.020 & 0.0017 & 0.070 \\
Fine silt & 0.006 & 0.0005 & 0.030 \\
Clay & 0.002 & 0.00017 & 0.010 \\
Fine clay & 0.0006 & 0.00005 & 0.003 \\
\hline
\end{tabular}

Table 5

Summary of the largest BSS found in the wider enlargement (Palun), BSS $_{\mathrm{cr}}$ for associated $\mathrm{z}_{0}$; all these shear stresses being expressed in $\mathrm{N} / \mathrm{m} .{ }^{2}$.

\begin{tabular}{llllll}
\hline Conditions & SC2A & SC3A & SC2B & SC3B & BSS $_{\text {cr }}$ \\
\hline Fig. 9a; $z_{0}=5 \mu \mathrm{m}$ & 0.18 & & & & 0.108 \\
Fig. 9b; $z_{0}=5 \mu \mathrm{m}$ & & 0.17 & & & 0.108 \\
Fig. 9a; $z_{0}=5 \mu \mathrm{m}$ & & & 0.04 & & 0.108 \\
Fig. 9b; $z_{0}=5 \mu \mathrm{m}$ & & & & 0.03 & 0.108 \\
Fig. $10 ; z_{0}=0.5 \mu \mathrm{m}$ & 0.21 & 0.23 & & & 0.030 \\
Fig. $10 ; z_{0}=0.05 \mu \mathrm{m}$ & 0.23 & 0.25 & & & 0.003 \\
\hline
\end{tabular}

$0.8 \mathrm{~g} / \mathrm{l}$ ) corresponding to peaks in wind stress of about $0.5 \mathrm{~N} / \mathrm{m}^{2}$. With estimated $\mathrm{u}_{* \mathrm{idm}} \max$ of about $0.3 \mathrm{~cm} / \mathrm{s}$ and $S S C$ of $40 \mathrm{mg} / \mathrm{l}$.

Their results concerning $\mathbf{u}_{*_{\mathrm{idm}}} \max$ in the prefrontal and frontal phases of both events are summarized in Table 6 in which we added the corresponding BSS values calculated from eq. (8).

A substantial resuspension (with $S S C$ of about $1000 \mathrm{mg} / \mathrm{l}$ ) is found when $\mathrm{u}_{* \mathrm{idm}}$ is maximum in the frontal phase for both events. Even in the prefrontal phases (with SSC ranging from 40 to $100 \mathrm{mg} / \mathrm{l}$ ) BSS reaches a value which is close to $B S S_{c r}$ shown in our Table 5 for the Rove channel.

Concerning erosion for fine sand and mud in the case of a typical continental shelf environment, Mengual et al. (2017) concluded that if the percentage of mud fraction is more than $70 \%$ the sediment behaves like a pure mud, with a critical BSS of the order of $0.1 \mathrm{~N} / \mathrm{m}^{2}$. In addition, they found a very rapid resuspension (with $S S C$ increasing to about 36 $\mathrm{mg} / \mathrm{l}$ in $15 \mathrm{mn}$ ) as soon as BSS is exceeding this critical value. Such a threshold for muddy sample well corresponds to the one found in section 6.4 .

The approach of Wu et al. (2018) who consider mud dry density (and/or water content) as an important parameter, is also well suited to the Rove sediments. Indeed, in the present study, the fraction of dry mater (shown in Table 7) is quite low, in particular for the surficial strata. This leads to an average value of raw (not-dehydrated) sediments of about $1250 \mathrm{~kg} / \mathrm{m}^{3}$ (after Fig.11 of IDRA, 2011), while the dry density of sediments (fine sand, silt, clay) is of about $2650 \mathrm{~kg} / \mathrm{m}^{3}$ (after Spencer, 2017).

To conclude and summarize the discussion we found that:

- For a bottom roughness of $5 \mu \mathrm{m}$ (coarse silt) and a wind speed of $20 \mathrm{~m} / \mathrm{s}, B S S$ can reach $0.18 \mathrm{~N} / \mathrm{m}^{2}$ for the N-NW wind in the median part of the channel, and even $0.21 \mathrm{~N} / \mathrm{m}^{2}$ in the Palun enlargement for the S-SE wind, while $B S S_{c r}=0.108 \mathrm{~N} / \mathrm{m}^{2}$ (Tables 4 and 5). So, it permits at least floc erosion, in the range 0.5 $B S S_{c r}<B S S<1.5 B S_{c r}$.

- For a lower bed roughness, we have shown that $B S S_{c r}$ is lower while the maximum of $B S S$ is larger. For instance, for $z_{0}=0.5 \mu \mathrm{m}$, $B S S_{c r}=0.03 \mathrm{~N} / \mathrm{m}^{2}$ (Table 5), while $B S S_{\max }$ is about $0.22 \mathrm{~N} / \mathrm{m}^{2}$ (Table 4). So, the conditions for the onset of floc erosion and even surface erosion (in the range $1.5 B S S_{c r}<B S S<3 B S S_{c r}$ ) are more easily reached for muddier sediments (fine silt and clay).

It is not in the scope of the present work to determine the erosion rate. But, for such a perspective, and as a first approximation, it would be probably appropriate, as suggested by Le Hir et al. (2011) and Mengual et al. (2017), to simply consider the erosion law for pure mud proposed by Partheniades-Ariathurai as:

$E_{\text {mиd }}=E_{0, \text { mud }}\left(B S S / B S S_{c r, \text { mud }}-1\right)^{n m}$, if $B S S>B S S_{c r, \text { mud }}$

with $n m$ equal to 1 , as most often in literature, and $E_{0, m u d}$ constant (equal to $10^{-5} \mathrm{~kg} / \mathrm{m}^{2} / \mathrm{s}$ ). 
Table 6

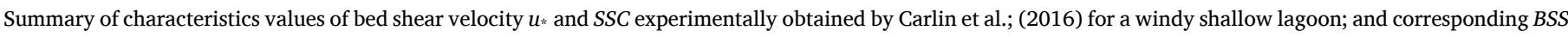
values from eq. (8).

\begin{tabular}{|c|c|c|c|c|c|c|}
\hline Conditions & $\begin{array}{l}\mathrm{u} * \text { idm } \max \\
\text { prefrontal phase } \\
(\mathrm{cm} / \mathrm{s})\end{array}$ & $\begin{array}{l}\text { BSS prefrontal phase } \\
\left(\mathrm{N} / \mathrm{m}^{2}\right)\end{array}$ & $\begin{array}{l}\text { SSC prefrontal phase } \\
(\mathrm{mg} / \mathrm{l})\end{array}$ & $\begin{array}{l}\mathrm{u} * \text { idm } \max \\
\text { frontal phase } \\
(\mathrm{cm} / \mathrm{s})\end{array}$ & $\begin{array}{l}\text { BSS frontal phase } \\
\left(\mathrm{N} / \mathrm{m}^{2}\right)\end{array}$ & $\begin{array}{l}S S C \text { frontal phase } \\
(\mathrm{mg} / \mathrm{l})\end{array}$ \\
\hline Event-1 & 0.7 & 0.06 & 100 & 1,4 & 0.20 & 1000 \\
\hline Event-2 & 0.7 & 0.06 & 40 & 2.0 & 0.41 & 1000 \\
\hline
\end{tabular}

Table 7

Fraction of dry mater (\%) of bottom sediment in stations S9-S13, after Tables 6a and $6 \mathrm{~b}$ of IDRA (2011).

\begin{tabular}{lllllll}
\hline Station & S9 & S10 & S11 & S12 & S13 & average per strata \\
\hline strata1 & 11 & 16 & 20 & 13 & 14 & $15 \%$ \\
strata2 & 16 & 23 & 23 & 17 & 23 & $20 \%$ \\
strata3 & 28 & 36 & 29 & 20 & 25 & $28 \%$ \\
\hline
\end{tabular}

\section{Conclusions}

This work concerns a numerical simulation of wind-driven hydrodynamics and resuspension in a narrow channel which confluences a wide brackish lagoon, and the risk of transport of contaminated bottom sediments to this lagoon, if a forced convection is imposed by pumping sea water at the head of the channel. Two main peculiarities are considered: muddy bottom sediments and winds blowing frequently in directions almost perpendicularly to the channel.

The evolution of the vertical salinity profiles has been analyzed along the channel. The results in section 4 show that:

- in absence of wind the vertical profiles of salinity exhibit a gradient near the surface which is associated to a downstream current at this surface coming from the brackish water of the lagoon.

- on the contrary, in the case of wind, the salinity is constant through the vertical direction, indicating a mixing in the water column even in the median portion of the channel (along tr1-tr3 transects) where the width is of about $74 \mathrm{~m}$ only.

- In both cases, the surface salinity decreases regularly from the entrance (38 PSU) to the exit (20 PSU) of the computational domain.

In order to study the risk of transport of pollutant in the Rove channel by the current in the case of forced convection (re-opening of the Rove tunnel), we mainly analyzed the bottom shear stress, and the condition for which BSS overpass the threshold value for the onset of bottom sediment mobility (erosion and resuspension). For muddy unconsolidated sediment, the erosion/resuspension threshold obtained experimentally by Mengual et al. (2017) for estuarine environment corresponds to $B S S=1 \mathrm{~N} / \mathrm{m}^{2}$.

The risk of pollution of the wide lagoon results from the combination of large BSS (leading to resuspension) due to local winds and forced convection which permits the transport of the suspended sediments towards the lagoon.

The results presented in section 5 for strong winds $(10 \mathrm{~m} / \mathrm{s}$ and $20 \mathrm{~m} /$ s) which are blowing very frequently in this area, show that such wind speeds are enough, despite the modest width of the Rove channel, to produce bottom shear stress larger than $1 \mathrm{~N} / \mathrm{m}^{2}$ BSS is maximum near the southern bank for the N-NW wind, and, on the contrary, near the northern bank for the S-SE wind. Most of the results are given for a sea water runoff $Q_{1}=3 \mathrm{~m}^{3} / \mathrm{s}$.

For a bottom roughness of $5 \mu \mathrm{m}$ and a wind speed of $20 \mathrm{~m} / \mathrm{s}, B S S$ can reach $0.18-0.21 \mathrm{~N} / \mathrm{m}^{2}$, while $B S S_{c r}=0.108 \mathrm{~N} / \mathrm{m}^{2}$. So, it permits at least floc erosion in the range $0.5 B S S_{c r}<B S S<1.5 B S S_{c r}$.

For a lower bed roughness, $B S S_{c r}$ is lower while the maximum of $B S S$ is larger. For instance, for $z_{0}=0.5 \mu \mathrm{m}, B S S_{c r}=0.03 \mathrm{~N} / \mathrm{m}^{2}$ (Table 5), while $B S S_{\max }$ is about $0.22 \mathrm{~N} / \mathrm{m}^{2}$ (Table 4). So, the conditions for the onset of floc erosion and even surface erosion (in the range $1.5 B S S_{c r}<B S S<3 B S S_{c r}$ ) would be more easily reached for muddier sediments (fine silt and clay).

There is not yet any experimental evidence of what it could happen in the case of forced convection inside the Rove channel. But, as surficial sediment remains unconsolidated in the today condition (without sea water pumping), this is probably a good indicator which confirms that the frequent wind regularly creates a local resuspension of these sediments. This situation is similar to the one mentioned by Mengual et al. (2017) for estuarine sediments which remain unconsolidated due to local activity.

Right now (i.e., for $Q_{1}=0$ ), the contaminated Rove sediments are redeposited at about the same place after each wind episode. But, they will move downstream (towards EB lagoon, in particular), as soon as a current would be generated by pumping sea water (i.e., for $Q_{1}>0$ ). The time needed for such a transport towards EB lagoon would be shorter and shorter if the imposed runoff $Q_{1}$ is increased.

Concerning the condition to obtain a bed sediment mobility (erosion and suspension), our numerical results for different wind forcings and different bottom roughness show that the mobility threshold can be easily overpassed for the muddy sediments in the Rove channel. This is quite consistent with the experimental studies of resuspension of muddy bed sediments presented by Carlin et al. (2016) for a shallow water lagoon and by Mengual et al. (2017) for estuarine conditions. The mobility threshold (of the order of $0.1 \mathrm{~N} / \mathrm{m}^{2}$ ) mentioned in this last paper is consistent with $B S S_{c r}$ shown in our Table 5. It is interesting to note, following Mengual et al. (2017), that such a lower critical BSS when the mixture is muddier is opposite to trends most often published.

Finally, as shown in Tables 4 and 5, the finer bed sediments are more easily suspended $\left(B S S_{c r}\right.$ of order $0.03 \mathrm{~N} / \mathrm{m}^{2}$ for fine silt and $0.003 \mathrm{~N} / \mathrm{m}^{2}$ for clay). So, it is important to remember that these sediments not only fix more efficiently inorganic/organic contaminants but they also have smaller particle fall velocity. So, the risk of downstream transport of pollution in the Rove channel would be larger and larger if the imposed runoff of pumped sea water would be increased.

This new knowledge concerning the crucial effect of winds on the resuspension of contaminated muddy sediments and thus the risk of their downstream transport, will be useful, not only for the managers of the Rove channel, but also for the managers of coastal sites involving channels, to not forget to pay attention on the wind stress, even for narrow channels.

\section{Declaration of competing interest}

The authors declare that they have no known competing financial interests or personal relationships that could have appeared to influence the work reported in this paper.

\section{CRediT authorship contribution statement}

E. Alekseenko: Conceptualization, Methodology, Visualization. B. Roux: Conceptualization, Methodology, Investigation.

\section{Acknowledgements}

We acknowledge financial supports by the French Ministry of 
Foreign Affairs (ARCUS-Russia program), by the French Water Agency (Agence de l'Eau-RMC - convention N2010-0042 and Ministry of Education and Science of the Russian Federation (Minobrnauka) - 01492019-0010.

\section{Appendix A. Supplementary data}

Supplementary data to this article can be found online at https://doi. org/10.1016/j.ecss.2020.106649.

\section{References}

Abrial, B., Hucher, D., 2017. Expertise sur le projet de réouverture du tunnel du Rove à la circulation d'eau de mer. Ministère de l'Environnement de l'Energie et de la Mer, rapport no 011009-01. avril 2017. http://www.ladocumentationfrancaise.fr/var/st orage/rapports-publics/174000457.pdf.

Alekseenko, E., Roux, B., 2018. Numerical simulation of the wind influ-ence on bottom shear stress and salinity fields in areas of Zostera noltei replanting in a Mediterranean coastal lagoon. Prog. Oceanogr. 163, 147-160. https://doi.org/ 10.1016/j.pocean.2017.05.001.hal-02111578. Elsevier, 2018.

Alekseenko, E., Roux, B., Fougere, D., Chen, P.G., 2017. The effect of wind induced bottom shear stress and salinity on Zostera noltii replanting in a Mediterranean coastal lagoon. Estuar. Coast Shelf Sci. 187, 293-305.

Alekseenko, E., Roux, B., 2019a. Contribution to remediation of brackish lagoon: 3D simulation of salinity, bottom currents and resuspension of bottom sediments by strong winds. Estuar. Coast Shelf Sci. 216, 27-37.

Alekseenko, E., Roux, B., 2019b. Wind effect on bottom shear stress, erosion and redeposition on Zostera noltei restoration in a coastal lagoon; part 2. Estuar. Coast Shelf Sci. 216, 14-26. https://doi.org/10.1016/j.ecss.2018.05.022.

Amos, C.L., Umgiesser, G., Ferrarin, C., Thompson, C.E.L., Whitehouse, R.J.S., Sutherland, T.F., Bergamasco, A., 2010. The erosion rates of cohesive sediments in Venice lagoon. Continent. Shelf Res. 30, 859-870.

Berenbrock, Ch, Tranmer, A.W., 2008. Simulation of Flow, Sediment Transport, and Sediment Mobility of the Lower Coeur d'Alene River, Idaho. U.S. Environmental Protection Agency. Scientific Investigations Report 2008-5093.

Blumberg, A.F., Mellor, G.L., 1986. A Description of a Three-Dimensional Coastal Ocean Circulation Model, Geophysical Fluid Dynamics Program. Princeton Univ., Princeton, New Jersey, pp. 1-16.

Carlin, J.A., Lee, G-h, Dellapenna, T.M., Laverty, P., 2016. Sediment resuspension by wind, waves, and currents during meteorological frontal passages in a micro-tidal lagoon. Estuar. Coast Shelf Sci. 172, 24-33.

Debnath, K., Chaudhuri, S., 2010. Cohesive sediments erosion threshold: a review. ISH Journal of Hydraulic Engineering 16 (1), 36-56. https://doi.org/10.1080/ 09715010.2010.10514987.

Debnath, K., Nikora, V., Aberle, J., Westrich, B., Muste, M., 2007. Erosion of cohesive sediments: resuspension, bed load, and erosion patterns from field experiments. J. Hydraul. Eng. 2007 133, 508-520. https://doi.org/10.1061/(ASCE)0733-9429 (2007)133:5(508).

Dufois, F., Le Hir, P., 2015. Formulating fine to medium sand erosion for suspended sediment transport models. J. Mar. Sci. Eng. 3, 906-934. https://doi.org/10.3390/ jmse3030906.

IDRA Environnement, 2011. Etude de risque associé aux sédiments dans le cadre de la reouverture experimentale du tunnel du Rove. Rapport GPMM. S 90301.

Kothyari, U.C., Jain, R.K., 2008. Influence of cohesion on incipient motion condition of sediment mixtures. Water Resour. Res. 44, W04410. https://doi.org/10.1029/ 2007WR006326.
Krone, R.B., 1984. The significance of aggregate properties to transport processes. In: J Mehta, A. (Ed.), Estuarine Cohesive Sediment Dynamics. Springer, Berlin, pp. 66-84.

Lazure, P., Dumas, F., 2008. An external-internal mode coupling for a 3D hydrodynamical model for applications at regional scale (MARS). Adv.Wat. Res. 31, 233-250.

Lazure, P., Garnier, V., Dumas, F., Herry, Ch, Chifflet, M., 2009. Development of a hydrodynamic model of the Bay of Biscay. Validation of hydrology. Continent. Shelf Res. 29 (8), 985-997.

Le Hir, P., 2008. Aide memoire de dynamique sedimentaire, 7eme edition. DYNECO/ PHYSED. https://archimer.ifremer.fr/doc/00000/6273/.

Le Hir, P., Cayocca, F., Waeles, B., 2011. Dynamics of sand and mud mixtures: a multiprocess- based modelling strategy. Continent. Shelf Res. 31, S135-S149.

L'Etang Nouveau Association, 2011. Des dauphins en Mediterranee, pourquoi pas dans l'Etang de Berre ? by Guy Imbert; AG Association Etang Nouveau, 8 oct. 2011. https ://letangnouveau.files.wordpress.com/2011/10/deb-ag-len-oct-20112.pdf.

Mathew, R., Winterwerp, J.C., 2017. Surficial sediment erodibility from time-series measurements of suspended sediment concentrations: development and validation. Ocean Dynam. 67, 691-712. https://doi.org/10.1007/s10236-017-1055-2.

Mengual, B., Le Hir, P., Cayocca, F., Garlan, T., 2017. Modelling fine sediment dynamics: towards a common erosion law for fine sand, mud and mixtures. Water 9 (8). https://doi.org/10.3390/w9080564, 564 (1-24).

Panagiotopoulos, I., Voulgaris, G., Collins, M.B., 1997. The influence of clay on the threshold of movement of fine sandy beds. Coast. Eng. 32, 19-43.

Perera, C., Wu, W., 2016. Erosion coefficients of cohesive sediments; world environmental and water resources congress 2016, 293-302. https://ascelibrary.or g/doi/abs/10.1061/9780784479872.030.

Pont, D., Barroin, G., 1993. Expertise écologique de l'étang de Bolmon en vue de sa réhabilitation. RAPPORT FINAL. U.R.A. 903 C.N.R.S., Marseille, 93p. https://www. documentation.eauetbiodiversite.fr/notice/expertise-ecologique-de-l-etang-de-bol mon-en-vue-de-sa-rehabilitation-rapport-final0.

Ramade, A., 1997. Ouverture du tunnel du Rove: incidence sur les echanges hydraulique; rapport Ramade-GERIM (aout 1997).

Righetti, M., Lucarelli, C., 2007. May the Shields theory be extended to cohesive and adhesive benthic sediments? Journal of Geophysical Research Atmospheres 112 (112), C05039.

SOGREAH, 2003. Berreau Etudes de premiere phase, Evaluation comparative des impacts maritimes des solutions B et T, rapport MAR/PSI- 2360023, 28 April 2003.

Spencer, K., 2017. Estuarine deposited sediments: sampling and analysis. In: Uncles, R., Mitchell, S. (Eds.), Estuarine and Coastal Hydrography and Sediment Transport. Cambridge University Press, Cambridge, pp. 153-178. https://doi.org/10.1017/ 9781139644426.007.

Sukhinov, A.I., Sukhinov, A.A., Roux, B., 2007. Reconstruction of basin bottom surface for high precision hydrodynamics modeling using parallel computations. In: Proc. Int. Conf. On Parallel CFD 2007, Antalya, Turkey, 21-24 May 2007. ParCFD-2007031.

van Rijn, L.C., 2016. Critical bed-shear stress for sand-mud mixture. Note : initiation of motion and suspension, 1 july 2016. http://www.leovanrijn-sediment.com/papers/ Thresholderosion2016.pdf.

Winterwerp, J.C., 1989. Flow-Induced Erosion of Cohesive Beds; A Literature Survey. Cohesive Sediments Report 25. Delft Hydraulics, p. 52.

Winterwerp, J.C., Van Kesteren, W.G.M., Van Prooijen, B., Jacobs, W., 2012. A conceptual framework for shear flow-induced erosion of soft cohesive sediment beds. J. Geophys. Res. 117, C10020.

Wu, W., Perera, C., Smith, J., Sanchez, A., 2018. Critical shear stress for erosion of sand and mud mixtures. J. Hydraul. Res. 56 (1) https://doi.org/10.1080/ 00221686.2017.1300195, 2018.

Young, I.R., 1999. Wind Generated Ocean Waves. Elsevier, 288pp. 